\author{
Chichinadze B. \\ Doctor of Economics, Associate Professor \\ Department of Economics \\ Kutaisi Akaki Tsereteli State University \\ Tamar Mephest, 59, Kutaisi, Georgia, 4600 \\ E-mail: borkach@mail.ru
}

\title{
CHARACTERISTICS OF LOCAL SELF-GOVERNMENT DEVELOPMENT IN GEORGIA
}

The article focuses on the fact that for decades, local governments in Georgia have not used their significant reserves effectively. Local governments also lack a modern plan for the socio-economic development of territories. It should be noted that for the significant development of local self-government, the priority of different areas has not been determined. Problematic issues were resolved spontaneously without the participation of local residents, without coordination and reconciliation. Despite the numerous local reforms that have been implemented since independence in Georgia, important issues such as the separation of powers between the center and self-government, lack of financial resources and assets, through decentralization, significant deficit competencies in the venture capital attraction, in the sense of self-governing competencies in securities issues and so on, remain unresolved.

It is necessary as soon as possible to adopt the necessary laws that ensure the economic development of local governments, which will lead to the significant improvement of the social conditions of citizens. If the central government does not take quick effective steps in this direction, the socio-economic situation in the self-government bodies of Georgia will deteriorate even more, which will jeopardize the country's financial and political stability.

Key words: local government, budgetary independence, investment, economic growth, investment attraction, political stability, financial sustainability.

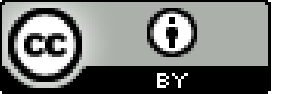

This work is licensed under a Creative Commons Attribution 4.0 International License http://creativecommons.org/licenses/by/4.0/
Statement of the problem and its connection with important scientific and practical tasks. After the collapse of the planned administrative - economic system in Georgia, as in any other post-socialist country, problems arose with local self-government, and the issue of changing the local self-government system was placed on the agenda. According to the current situation, decentralization of power was necessary in order to significantly increase the managerial competencies of local authorities.

The development of self-government dates back to the $\mathrm{BC}$ era. At that time they were not yet referred to as self-government. Ancient economic sources contain scarce information about such territorial entities.

In the "Code of Hamurabi" decreed by the King of Babylon (1792-1750 BC) (discovered by the Archaeological Expedition of France in 1901), it is briefly stated that there were also associations of local communities that had powers and owned public lands. Each member of the community had to participate in the construction of irrigation facilities, so the communities had certain responsibilities to the King.

The existence of communities is also briefly mentioned in the writings of Mencious or Menzgi (372289 BC), an important representative of ancient Chinese economic thought. He defended the rights of communities from violence by the state, noting that the role of communities is important for the development of the entire state. He viewed moderation as a key means of community development in collecting state taxes.

Little information about the functioning of the communities is also given in the Guanzi text by unknown Chinese authors (4th -3 rd centuries BC), which mainly addresses the issues of public administration of that period. According to the agreement, if the ruler controls the issues of bread, money and metals, then the whole country will have a stable life [1].

According to various scholars of that time, due to the study of territorial economic units the socioeconomic potential of local self-government began to be studied, as a result of which it would be possible to conduct a thorough analysis of the intensive development of territorial bodies.

Local governments in Georgia have not used their significant reserves effectively. Local governments also lack a modern plan for the socio-economic development of territories. Speaking about Georgia, based on the emergency situation (coronavirus pandemic and related economic problems), it should be noted that the municipalities of Georgia must have comprehensive plans for socio-economic development. These plans should become the basis for municipalities to create indicative plans that can be presented in the short term (1- 
2 years), medium term (3-5 years) and in the long term (5 years or more) period, taking into account all potential risks and considering protection mechanisms. After measures taken in Georgian municipalities, criteria tested in developed countries of the world that determine the economic situation of local municipalities should be used to determine the current socio-economic situation in municipalities, for example: regional and municipal indicators in accordance with GDP, incomes and expenditures of the local budget per capita, average life expectancy, employment rate, access to education, crime rate, per capita investment, demographic situation and so on. Improving the socio-economic situation of Georgian municipalities, and using the rich scientific potential in the country, should become one of the main strategic goals of the central government.

The analysis of the latest publications on the problems. It is noteworthy that in the 19th and 20th centuries, public debates about local self-government in Georgia were conducted by such great, famous and patriotic Georgian thinkers as Ilya Chavchavadze, Niko Nikoladze, Mikhako Tsereteli and others. Local government, as an institution in Georgia ,was approved by the Constitution in 1921.

Observation of the history of self-government and its development showed that:

Local self-governance - is the right and power of citizens and communities to resolve the local-scale issues independently;

Local self-governance - is a form of governance when people make decisions on local issues within their competence;

Local self-governance - is a form of social governance that operates in agreement with the state government.

Local self-governance - is one of the important constitutional structures that provides a hierarchy of government through the distribution of power [10].

In addition, it is necessary to take into account the opinion of Georgian and foreign scientists and experts which claims that public administration cannot be sustainable if it is not supported by effective local selfgovernment.

The development of local governments mainly determines the improvement of the economic situation in the country and the viability of the population. Historically, the development of local formations largely depended on the development of a self-governing agricultural sector, since the share of local agriculture in the country's overall economy used to be very high [2].

Forming of the aims of the research. Despite the reforms undertaken after the declaration of independence in Georgia (since 1991), the decentralization system in Georgia still faces serious problems that open up the possibility for society to discuss the prospects for further reforms of local self-government in this country.

It should be noted that the concept of socioeconomic well-being of self-government bodies is not clearly defined in the economic literature. Some scientists and economists have in mind the socio-economic situation in one area or the welfare of the local economy and population. Scientists and economists agree that if a municipality has a normal/average employment and income rate, provided by social spheres, an average quality and standard of living, as well as favorable conditions for the continuation of production, then such municipalities can be called the ones with socio-economic welfare. That is why the purpose of this article is to study and characterize the development of local self-government in Georgia.

In my opinion, the indicators that determine the socio-economic well-being of self-government bodies are as follows:

a) local social microclimate and environmental quality;

b) the proportion of unemployed in relation to able-bodied citizens living in local communities;

c) nominal monthly salary;

d) employment/unemployment rate;

e) number of recorded crimes per 1000 inhabitants;

f) number of passengers transported to the municipality during the year;

g) quality of telephone communications and Internet access of local residents;

h) Share/rate of revenues and expenses of the local budget, as well as per capita investments in local authorities.

The development of municipalities is mainly reflected in the rational use of the natural, industrial, scientific, labor, social and cultural potential of facilities to ensure the growth of business activity of citizens [9].

Giving an account of the main results and their substantiation. According to the experts, the importance of investment attractiveness and risk assessment are of great importance in determining the socioeconomic status of municipalities. It is well known that the investment potential of municipalities are:
a) labor resources;
b) production level and its development ;
c) institutional capacity building;
d) development of local infrastructure;
e) financial potential.
We can consider the following risks:

a) financial risks associated with the quality of local budgeting and financial management;

b) risks associated with the municipal governance and its quality;

c) risks associated with the municipal debt management and debt obligations/municipal bond [3].

For a serious study of the socio-economic status of local governments, it is necessary to modernize local capital and territorial infrastructure, and for this it is necessary to maximize the use of local human capital. It is also necessary to determine the institutional and economic status of local economic systems as part of the country's overall economy [5]. 
Local economic development policies must be clearly defined in order to set specific goals. The following aspects can be distinguished:

a) equitable distribution of the local budget revenue:

b) providing the local population with appropriate standard of living

c) local economic development;

d) creating a better local business environment;

e) achieving maximum employment;

f) improving local environment and ecology;

To achieve these goals, the central government should enact laws to effectively address the issues raised.

Historically, differences between individual municipalities used to influence the country's policy, therefore, the need arose to develop local economic policies that would be adapted to local characteristics [6].

In recent years, Georgia has not had a comprehensive legislative framework that would provide for an increase in the power to adopt local legislative acts at the local level. That experience exists in many foreign countries, including France, Switzerland, Japan, Canada, and the USA. Provinces, departments, districts, prefectures, mayors' offices and municipalities in these countries have the right to enact laws at the local level. Sometimes, the enacted laws, to some extent, restrict laws adopted at the central level. Local governments of these countries secure greater budget independence with the help of these laws, which is a prerequisite for the effective resolution of local issues.

Given that without improving the economic conditions of local self-government the development of the country's economy is almost unimaginable, it is extremely important to pursue a reasonable economic and legal policy in local self-government [7].

Since 1991, the central government of Georgia has not used any differentiated approaches to the development of local municipalities, which, in its turn, could improve the local socio-economic status. Local politics did not imply a state concept, no proper legislative framework has been created. Due to the uncertain and unclear future of local municipalities, which exacerbated the difficult economic and criminal situation in the country, the labor and entrepreneurial activity of the local population sharply decreased, unemployment increased significantly which caused economic recession. The budgetary independence of local municipalities decreased year by year [4].

The rapid economic downturn has led to imbalances in the development of local self-government. This was reflected in such significant changes in the ratio per capita as: investments, financial income and expenses, industry and agricultural production, life expectancy, the provision of services to educational and cultural facilities, etc.

With regard to the development of local self- government as a whole, the following scientific approaches can be distinguished:

1) determining conceptual aspects of the local economic system and its development;

2) studying the development of specific features of the local economic system.

3) studying the administrative form and specifics of the local economic system;

4) identification of opportunities to use modern scientific achievements for the development of local municipalities;

5) determining the mission and key functions of local municipalities;

6) determining the role of local municipalities in the development of regional and national economies;

7) analysis of laws and regulations adopted at the local level to diversify the budget revenues of local municipalities;

8) learning various aspects of development from the experience of foreign local municipalities [8].

Conclusions and prospects of the further investigations. Based on this article, we can confidently say that the local municipalities of Georgia have great development prospects only if there is political will on the part of the central government for the development of municipalities. A proper assessment of the relationship between the Center and the municipalities in the political and socio-economic spheres should be a prerequisite for the development of municipalities. This requires a systematic approach to existing problems, familiarization with the experience of other countries and the exchange of knowledge in the field of the local management system. Identification and assessment of the resource potential of municipalities, effective use of human capital available on the spot is a matter of great importance.

It is safe to say that, at this stage, the introduction of modern European self-government experience does not take place in Georgian municipalities. The current situation significantly impedes the further development of local self-government, and their dependence on the center increases even more.

As you know, without real local self-government it is impossible to increase the well-being of the country's population. Observations of recent years (1993-2019) and an analysis of the processes taking place in local government bodies have shown that important legal and economic reforms need to be implemented in the local government bodies of Georgia. The emergency situation created today in the world will force the central government to make extraordinary, bold and result-oriented decisions regarding municipalities so that the processes carried out in the municipalities become adapted to reality and do everything in order to significantly increase the international recognition and investment attractiveness of the Georgian municipalities. These steps will be the basis for increasing the welfare of citizens of all municipalities. 


\title{
References
}

1. Silagadze, A. (2000). Economic Doctrines. Tbilisi.

2. Chitanava, N. (2001). Socio-economic problems of the transition period. Research Institute of Economic and Social Problems of the Ministry of Economy of Georgia. Tbilisi.

3. Chichinadze, B. (2015). Problems and Prospects of Local Government Development. Business and Legislation, (4), 10-14.

21-26.

4. Chichinadze, B. (2013). What hinders the development of self-governments. Business and Legislation, (4),

5. Richarddson, H. W. (1995). Regional Growt Theory. London.

6. Robinson, E. A. (1969). Location Theory. Regional Economics and Backwards areas. New-York. doi: 10.1007/978-1-349-15315-2_1

7. Siebert, H. A., (1969). Regional Economics Growth: Theory and policy.

8. Tinbergen, J. (1995). Development Planning. London.

9. Sachs, J. D., \& Warner, A. M. (2000). The World Competitiveness Report Davos (rep.). Davos, 1-8.

10. Hart, A. (1992). Rival Capitalist: international competitiveness in the United State, Japan and Western Europe. L. Cornell University Press. doi: 10.7591/9781501725531

Received 4 June 2020

Approved 18 June 2020

Available in Internet 15.10.2020

\author{
Чичинадзе Б.Д. \\ доктор экономических наук, доцент \\ кафедра экономики \\ Кутаисский государственный университет им. Ак.Церетели \\ ул. Царицы Тамары, 59, г. Кутаиси, Грузия, 4600 \\ E-mail: borkach@mail.ru
}

\section{ОСОБЕННОСТИ РАЗВИТИЯ МЕСТНЫХ САМОУПРАВЛЕНИЙ ГРУЗИИ}

В статье большое внимание уделяется тому, что на протяжении десятилетий в местных самоуправлениях Грузии не использовались существующие на местах важные ресурсы. Местные самоуправления не имеют современных социально-экономических программ развития территории. Необходимо отметить, что для значительного развития местных самоуправлений не была выявлена приоритетность различных направлений. На местах проблемные вопросы решались спонтанно, без участия местных граждан и без согласования с ними вопросов. Несмотря на многие проведенные местные рефрормы со для независимости Грузии, снова нерешенным остается вопрос таких важных тем, как раздел компетенций между центром и самоуправлениями, недостаток местных финансов и имущества, низкое качество децентрализации, значительный дефицит компетенций местных должностных лиц в направлении привлечения инвестиций. Низкий уровень компетенции на местных уровнях в направлении выпуска ценных бумаг и др.

Исходя из сегодняшнего положения самоуправлений Грузии можем отметить, что центральной власти ещё многое предстоит сделать для того, чтобы выросла бюджетная независимость местных самоуправлений. Цель данной статьи - изучить и охарактеризовать развитие местного самоуправления в Грузии, что обусловлено актуальностью выбранного направления исследования. Необходимо, чтобы центральная власть путём консультации и сотрудничества с местными самоуправлениями, изучила те факторы, которые вызывают ухудшение социально-экономического положения местных самоуправлений и в сжатые сроки принять такие законы, которые обеспечат экономическое развитие местных самоуправлений и значительно улучшат социальное положение живущих в них граждан. Если со стороны центральной власти в скором времени не будут сделаны действенные шаги в этом направлении, тогда социально-экономическое положение в местных самоуправлениях станет более напряжённым, что в целом создаст опасность для финансовой и политической стабильности страны. Нужно отметить, что необходимость проведения быстрых реформ в местных самоуправлениях ставит также на повестку дня подписанный между Грузией и Евросоюзом ассоциированный договор о сотрудничестве.

Ключевые слова: местное самоуправление, бюджетная независимость, инвестиции, экономический рост, привлечение инвестиций, политическая стабильность, фринансовая устойчивость. 


\author{
Чічінадзе Б.Д. \\ доктор економічних наук, доцент \\ кафедра економіки \\ Кутаїський державний університет ім. Ак.Церетелі \\ вул. Цариці Тамари, 59, м. Кутаїсі, Грузія, 4600 \\ E-mail: borkach@mail.ru
}

\title{
ОСОБЛИВОСТІ РОЗВИТКУ МІСЦЕВОГО САМОВРЯДУВАННЯ ГРУзІї
}

\begin{abstract}
У статті велика увага приділяється тому, що протягом десятиліть в місцевих самоврядуваннях Грузії не використовувалися існуючі на місцях важливі ресурси. Місцеві самоврядування не мають сучасних соціально-економічних програм розвитку території. Необхідно відзначити, що для значного розвитку місцевих самоврядувань була виявлена пріоритетність різних напрямів. На місцях проблемні питання вирішувалися спонтанно, без участі місцевих громадян і без узгодження з ними питань. Незважаючи на багато проведених місцевих реформ зі для незалежності Грузії, знову невирішеним залишається питання таких важливих тем, як розділ компетенцій між центром і органами самоврядування, недолік місцевих фінансів та майна, низька якість децентралізації, значний дефіцит компетенцій місцевих посадових осіб щодо залучення інвестицій. Низький рівень компетенції на місцевих рівнях щодо випуску цінних паперів та ін.

Виходячи з нинішнього стану самоврядувань Грузії можемо відзначити, що центральній владі ще багато що належить зробити для того, щоб виросла бюджетна незалежність місцевих самоврядувань. Метою цієї статті було вивчити та охарактеризувати розвиток місцевого самоврядування в Грузії, що обумовлене актуальністю обраного напряму дослідження. Необхідно, щоб центральна влада шляхом консультацій і співробітництва з місцевими органами самоврядування, вивчила ті чинники, які викликають погіршення соціально-економічного становища місцевих самоврядувань і в стислі терміни прийняти такі закони, які забезпечать економічний розвиток місцевих самоврядувань і значно поліпшать соціальне становище громадян, що живуть в них. Якщо з боку центральної влади незабаром не будуть зроблені дієві кроки в цьому напрямі, тоді соціально-економічне становище в місцевих самоврядуваннях стане більш напруженим, що в цілому створить небезпеку для фрінансової і політичної стабільності країни. Потрібно відзначити, що необхідність проведення швидких реформ в місцевих самоврядуваннях ставить також на порядок денний підписаний між Грузією і Євросоюзом асоційований договір про співпрацю.
\end{abstract}

Ключові слова: місцеве самоврядування, бюджетна незалежність, інвестиції, економічне зростання, залучення інвестицій, політична стабільність, фрінансова стійкість.

\section{Література}

1. Silagadze A. Economic Doctrines. Tbilisi, 2000. 610 p.

2. Chitanava N. Socio-economic problems of the transition period; Scientific Research Institute of Economic and Social Problems of the Ministry of Economy of Georgia. Tbilisi, 2001. 422 p.

3. Chichinadze B. Problems and Prospects of Local Government Development // Business and Legislation. 2015. №4, P.10-14. P. 21-26.

4. Chichinadze B. What hinders the development of self-governments // Business and Legislation. 2013№4,

5. Richarddson H. W. Regional Growt Theory. London, 1995. 264 p.

6. Robinson E. A. (1969) Location Theory. REgional Economics and Backwards areas. New-York, 1969, pp. 3-20. doi: 10.1007/978-1-349-15315-2_1

7. Siebert H.A. Regional Economics Growth: Theory and policy, 1969. 217 p.

8. Tinbergen J. Development Planning. London, 1995. 256 p.

9. Sachs J.D., Warner A.M. The World Competitiveness Report Davos. Davos; 2000. 8 p

10. Hart A. Rival Capitalist: international competitiveness in the United State, Japan and Western Europe. L. Cornell University Press, 1992. 305 p. doi: 10.7591/9781501725531

Стаття надійшла 4.06.2020

Стаття прийнята до друку 18.06.2020

Доступно в мережі Internet 15.10.2020

Цитування згідно ДСТУ 8302:2015

Chichinadze B. Characteristics of local self-government development in Georgia // Food Industry Economics. 2020.

Vol.12, issue 3. P. 88-92. doi: 10.15673/fie.v12i3.1820

Cite as APA style citation

Chichinadze, B. (2020). Characteristics of local self-government development in Georgia. Food Industry Economics,

12(3), 88-92. doi: 10.15673/fie.v12i3.1820 